EESTI NSV TEADUSTE AKADEEMIA TOIMETISED. 19. KOIDE

KEEMIA * GEOLOOGIA. 1970, Nr. 1

ИЗВЕСТИЯ АКАДЕМИИ НАУК ЭСТОНСКОИ ССР. ТОМ 19

ХИМИЯ * ГЕОЛОГИЯ. 1970, Nㅛ 1

C. БАУКОВ

\title{
АКТУАЛЬНЫЕ ВОПРОСЫ ЭКОНОМИЧЕСКОЙ ГЕОЛОГИИ ПРИБАЛТИЙСКОГО СЛАНЦЕВОГО БАССЕЙНА
}

\author{
Использование непервоклассных \\ сортов топлива (торф, уголь худших \\ сортов) для получения электрической \\ энергии с наименьшими затратами на \\ добычу и перевоз горючего. В. И. Л е- \\ н и н. Набросок плана научно-техни- \\ ческих работ. ПСС, т. 36 , стр. 231.
}

Горючие сланцы-кукерситы Прибалтийского сланцевого бассейна (ПСБ) относятся к низкосортным видам минерального топлива, но дешевизна их добычи (3 руб. за гонну), благоприятные горно-геологическне условия разработки месторождения, большие запасы в недрах и близкое расположение к потребителям делают выгодным их использование на месте добычи для получения электрнческой энергии и для химической переработки. Так, на долю ПСБ приходится сейчас более $75 \%$ разведанных запасов промышленных категорнй и более $95 \%$ общей добычи сланцев Советского Союза. Количество добываемого здесь за год горючего сланца близко к годовой добыче угля во всей дореволюционной Рсссии и составляет около $1 \%$ от общего производства всех видоз топлива или около $2 \%$ от добычи угля СССР. Уже достигнутый уровень добычи сланца и намечаемое на ближайшие годы значительное увеличение промышленного освоения ПСБ требуют осуществления мероприятий по наиболее рациональному использованию его ресурсов.

В данной статье рассматриваются связанные с этой проблемой наиболее важные вопросы экономической геологии сланцевого бассейна, необходимость решения которых вытекает также и из общих задач рационального использования минеральных ресурсов, обсуждавшихся 29/IX - 3/X 1967 г. в Ростове-на-Дону на Третьем геологическом совещании по твердым горючим ископаемым и 8-10/IV 1969 г. в Москве на Межотраслевом научно-техническом совещании по рациональному использованию запасов полезных ископаемых при их добыче.

Серьезную тревогу вызывает в первую очередь недостаточно полное извлечение сланцедобывающей промышленностью балансовых запасов сланца при разработке месторождения. Так, по отчетным данным за 1968 год, общие потери сланца при добыче на шахтах и разрезах ПСБ составили 9,6 млн $T$, в том числе в Эстонской ССР 7,8 млн т и в Ленинградской области 1,8 млн т, или соответственно 33,2 и $35,3 \%$ погашенных за год балансовых запасов. Уровень потерь сланца при добыче имеет генденцию расти из года в год. Сокращение потерь сланца при добыче хотя бы на одну треть позволит сохранить запасы для деятельности двух крупных сланцедсбывающих предприятий или увеличить соответственно амортизационный срок службы действующих шахт. Это очень важно, если учесть, что все резервные шахтные поля для нового шахтного 
строительства по сравнению с полями действующих шахт и разрезов характеризуются менее качественным сланцем и более сложными условиями разработки, о чем речь будет еще впереди.

Предварительное изучение этого вопроса показало, что основными причинами таких больших показателей потерь сланца при добыче являются следующие.

Во-первых, завышенные требования потребительских ГОСТов на качество товарного сланца против среднего качества сланца в подготовленных запасах вынуждают при выборочной отработке промышленного пласта сланца оставлять часть его в недрах и терять часть отбитого сліанца в процессе обогащения. Чтобы привести в соответствие требования потребителей и природные показатели по качеству сланца, в первую очередь необходимо проверить достоверность данных геологоразведки и правильность принятой при подсчете запасов минимальной промышленной калорийности сланца. С другой стороны, необходимо дать технико-эксномическое обоснование возможного снижения показателей потребительских ГОСТов на качество товарного сланца, учитывая новейшие достижения науки и техники в использовании низкосортных высокозольных топлив. Это позволит также определить рациональные способы и оптимальные пределы обогащения при подготовке товарного сланца, что в свою очередь будет способствовать снижению потерь сланца и при добыче. Так, например, в настоящее время при открытом способе добычи обогащение сланца не производится, и поэтому выемка промышленного пласта ведется на неполную его мощность (в почве остается сланцевый слой A), а также теряется часть отбитого сланца из слоя $\mathrm{D}$, верхних частей слоев $\mathrm{C}$ и $\mathrm{F}$ и приконтактной части слоя $\mathrm{B}$. Все это ведет к тому, что при открытой разработке процент потерь сланца почти такой же высокий, как и при подземной добыче.

Второй причиной потерь сланца при добыче, по-видимому, является несоответствие применяемых методов добычи й систем разработок горно-геологическим условиям месторождения, что ведет к потерям сланца по геологическим причинам (главным образом, в зонах «древнего карста», «тектонических нарушений» и примыкающих к «древним эрозионным долинам») и вследствие неправильного ведения горных работ (главным образом неподходящие виды и излишние размеры целиков). Для устранения этой причины необходимо: изучать инженерно-геологические условия месторождения, в частности физико-механические свсйства пород кровли и почвы горных выработок и их устойчивость, данные о которых в настоящее время недостаточны для решения практических вопросов управления кровлей; совершенствовать методику геологоразведочных работ по выявлению горно-технических условий месторождения; совершенствовать методы и способы добычи сланца.

Третья причина потерь сланца при добыче заключается несомненно в том, что сланцедобывающие предприятия и их работники экономически не заинтересованы в наиболее полном и качественном извлечении запасов сланца из недр и не несут ответственности за невыполнение этого требования. Мероприятия по устранению этой причины носят чисто организационный и административный характер. Проведение их в жизнь возможно лишь в целом по отрасли производства в системе министерства или в общегосударственном масштабе.

В какой-то мере потери сланца при добыче обусловлены и упомянутой выше недостаточной полнотой данных геологоразведочных работ по установлению запасов и выявлению горно-геологических условий месторождения. Об этом упоминается здесь еще раз в связи с необходимостью обратить внимание на то, что детальная разведка месторождения, 
проводимая организациями геологических управлений, не может дать по тому или иному шахтному полю полную геологическую информацию (о закономерности тектонического строения шахтных полей, об изменчивости вешественного состава и свойств горючих сланцев в залежи и др.) в той мере, в какой это требуется для принягия мер по снижению потерь сланца при добыче. Это уже входит непосредственно в задачи шахтной геологической службы, которую требуется неотложно (особенно на шахтах треста «Эстонсланец») усилить кадрами, оснастить гехнически и материально и обеспечить правовыми нормами. Геологи на шахтах вместе с маркшейдерами - это глаза и уши государства на страже правильного ведения работ по эксплуатации месторождений полезных ископаемых. Неудовлетворительно поставленная служба шахтной геологии является сама по себе причиной потерь сланца при добыче, в частности, например, вследствие несовершенства существующих на шахтах методов определения и учета потерь и движения запасов. Если к этому еще добавить, что у нас отсутствует обоснованная методика для исчисления нормированных потерь сланца, то можно утверждать, что Управление государственного горно-технического надзора практически лишено возможности действенно (а не формально) контролировать положение дела в этой области. В то же время требуется тщательно сверять отчетные данные сланцедобывающих прсдприятий о потерях сланца с фактическими потерями.

Учет потерь сланца при добыче не должен быть формальным, как это наблюдается сейчас, и совершенствование его не должно являться самоцелью. Потери, составляющие значительную часть отрабатываемых запасов (не менее $30-35 \%$ по отчетным данным, а фактически, по-видимому, более $40 \%$ ), существенно способствуют непроизводительному уменьшению балансовых запасов и сроков службы действующих сланцевых шахт и разрезов. Правильный учет потерь сланца при добыче в пределах горных отводов шахт и разрезов необходим прежде всего для разработки и осуществления мероприятий по их снижению, для определения наиболее обоснованного коэффициента извлечения запасов при эксплуатации месторождения и правильного подсчета промышленных запасов сланца в недрах ПСБ.

Второй проблемный вопрос экономической геологии ПСБ касается кондиций на горючий сланец для подсчета запасов; от правильного решения его зависит нормальный ход геологоразведочных работ по подготовке новых шахтных полей и пересчету ранее разведанных запасов. Қондиции на качество сланца для подсчета запасов по ПСБ установлены в 1965-1966 г. неправильно, а именно отдельно для Әстонского и для Ленинградского месторождений и по средним показателям качества сланца на этих месторождениях, вместо единых кондиций для бассейна и по показателю качества, минимально приемлемого для промышленного освоения. Это неизбежно привело к тому, что на Эстонском месторождении геологоразведчики не могут взять на баланс запасы сланца порядка 1 млрд т, в то время как на Ленинградском месторождении, составляющем единое целое с Эстонским, запасы сланца такого же и более низкого качества, а также находящиеся в залежи с более сложными горно-геологическими и гидрогеологическими условиями, отнесены к балансовым. Более того, при пересчете разведанных до 1965 года балансовых запасов, значительная часть их по новым кондициям переходит в забалансовые.

Из-за этого на Эстонском месторождении практически нет резервных полей для нового шахтного строительства. В кондициях со средними показателями качества сланца по месторождению заложена ос- 
нова потерь сланца при добыче, так как исходя из них, планирующие органы устанавливают завышенные показатели качества товарного сланца. Разработка кондиций для подсчета запасов по отдельным участкам месторождения, как это вынуждены делать на Әстонском месторождении, например, для так называемого «Причудского участка», не решает поставленного вопроса в целом. Кондиции на горючий сланец для подсчета запасов по всему ПСБ требуют серьезного геолого-экономического обоснования, на основе чего можно и нужно будет произвести геолого-промышленную переоценку бассейна и его районирование.

Третий вопрос экономической геологии ПСБ касается комплексного использования запасов горючих сланцев и торфа, залежи которых располагаются на одной и той же площади. На территории Эстонии такими площадями являются поля открытых разработок горючего сланца -это поля сланцедобывающих разрезов 1, 2 и 3. В настоящее время только на поле разреза «Вийвиконна» производится предусмотренная проектом отработка сначала залежи торфа (ныне действующее торфяное предприятие «Ору»), после которой будет добываться горючий сланец. На полях разрезов 1, 2 и 3 отработка торфа проектом не предусмотрена, хотя здесь выше сланцевой залежи, в так называемой мягкой вскрыше, почти повсеместно залегает торф со средней мощностью $2 \mu$, а в отдельных местах и больше (в южной части поля разреза 3 - до 6 м). Несомненно, залежи торфа здесь представляют промышленную денность, о чем можно судить даже по весьма приближенным подсчетам, а именно: отношение приходящегося на единицу площади сланцевого топлива к торфяному (приведено к условному топливу) равно $2,0-2,5: 1,0$. При этом теплотворная способность воздушно-сухого торфа в полтора-два раза болыше, чем товарного сланца. Добавка торфа к сланцу в количестве, пропорциональном его долевому участию в залежи, повысит теплотворную способность товарного топлива примерно

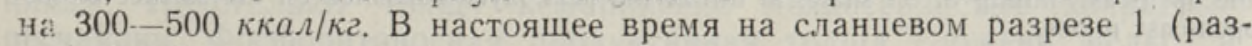
резы 2 и 3 еще строятся) торф теряется в отвалах, и его невозможно использовать даже для рекультивации отработанных площадей. По-видимому, целесообразно будет рассмотреть вопрос об̆ энергетическом использовании торфа совместно с горючим сланцем. В первую очередь следует обязать сланцедобывающие предприятия взять на баланс запасы торфа на горных отводах сланцевых разрезов 1,2 и 3 , чтобы заставить их форсировать решение этого вопроса.

Это далеко неполный перечень природных, технических и экономнческих факторов, от которых зависит решение вопросов, касающихся улучшения условий добычи, снижения себестоимости добычи сланца и болєе полного рационального использования запасов сланца ПІСБ. Аналсгичные вопросы экономической геологии ждут решения и для других полезных ископаемых нашей республики, например для фосфоритов н строительных материалов. Несомненно, для успешной реализации проблемы рационального использования полезных ископаемых республикн должны быть объединены усилия геологоразведчнков, горнодобывающих предприятнй, потребителей горнорудной продукции н соответствующих научно-исследовательских и проектных организаций. В pecпублике необходимо проводить научно-исследовательские работы по эксномике минерального сырья; такое направление работ целесообразно развивать в системе Академии наук, где имеются для этого определеннье предпосылки.

Межотраслевое научно-техническое совещание по рациональному нспользованию запасов полезных ископаемых при нх добыче обратилось ко всем работникам горнодобывающей промышленности, научно 
*

исследовательских, проектных и геологоразведочных организаций с призывом принять эффективные меры для решения задач наиболее полного и комплексного использования запасов полезных ископаемых в ознаменование столетия со дня рождения Владимира Ильича Ленина.

\author{
Институт геологии \\ Академии наук Әстонской ССР
}

Поступила в редакцию 20/X 1969

\title{
S. BAUKOV
}

\section{BALTI PŌLEVKIVIBASSEINI MAJANDUSGEOLOOGIA AKTUAALSED KUSIMUSED}

Balti põlevkivibasseini ressursside ratsionaalsemaks kasutamiseks soovitab autor vähendada pōlevkivi kaevandamisel esinevaid kadusíd, muuta bilansiliste varude määramisel põlevkivi kvaliteedi konditsioone ja pölevkivi lahtisel kaevandamisel ühtlasi kasutusele vōtta karjääriväljadel lasuv turvas.

\section{S. BAUKOV}

\section{TOPICAL QUESTIONS OF THE ECONOMIC GEOLOGY OF THE BALTIC OIL SHALE BASIN}

For a rational utilization of the resources of the Baltic oil shale basin, the author recommends to cut the losses connected with the mining of oil shale, to change the qualitv standards of oil shale at the determination of balance resources, and, simultaneously with the open-cast mining of oil shale, to utilize the peat layer deposited on the surface of the open-cast mines. 